\title{
Differences in Cardiovascular Risk Factors in Swedes and Assyrians/Syrians with Type 2 Diabetes: Association with Lifestyle-Related Factors
}

\author{
Marina Taloyan ${ }^{1 *}$, Nuha Saleh-Stattin¹, Sven-Erik Johansson ${ }^{1,2}$, Lars Agréus ${ }^{1}$ and Per Wändell ${ }^{1}$ \\ ${ }^{1}$ Karolinska Institutet, Center for Family and Community Medicine, Alfred Nobels allé 12, SE -141 83 Huddinge Sweden \\ ${ }^{2}$ Center for Primary Health Care Research, Region Skåne, Lund University, UMAS, 20502 Malmö, Sweden
}

\begin{abstract}
Aims: The aims of this study were [1] to estimate the prevalence of some cardiovascular risk factors among Assyrians/Syrians $(n=173)$ and Swedes $(n=181)$ with type 2 diabetes and [2] to analyze whether any association between ethnicity and cardiovascular risk factors remained after adjustment for lifestyle-related factors.

Methods: The associations between lifestyle-related factors and the outcome variables were calculated using unconditional logistic regression.

Results: Statistically significant differences were in the prevalence of elevated triglycerides, found in $61.5 \%$ of Swedes and $39.7 \%$ of Assyrians/Syrians. The same pattern was found in the prevalence of hypertension, which was $\mathbf{7 7 . 0 \%}$ in Swedes and $58.0 \%$ in Assyrians/Syrians. In the final logistic models, adjusted for age, sex, body mass index, total weekly physical activity in winter, alcohol consumption and smoking, the odds ratios (ORs) of elevated triglycerides and hypertension remained significantly higher in Swedes than in the Assyrian/Syrian group. The OR of elevated triglycerides in Swedes was 3.74 (95\% Cl 1.95-7.20) and of hypertension, 2.95 (95\% Cl 1.61-5.41).
\end{abstract}

Conclusions: The higher odds of triglycerides and hypertension in Swedes could not be explained by the factors included in this study; future studies could focus on other factors, including biological factors that might help explain the differences.

Keywords: Ethnicity; Cardiovascular; Life style; Type 2 diabetes mellitus; Sweden

Abbreviations: BMI: Body Mass Index; CI: Confidence Interval; CVD:
Cardiovascular Disease; OR: Odds Ratio; WC: Waist Circumference

\section{Introduction}

Individuals with type 2 diabetes are at higher risk of cardiovascular diseases (CVD) $[1,2]$ than those without type 2 diabetes. Diabetes is a chronic disease with severe complications and is a growing health issue in Europe and Sweden as well as in other parts of the world. The prevalence of diabetes in Sweden, mainly type 2, is about 4.5\% $[3,4]$.

Diabetes, dyslipidemia, hypertension and obesity are well-known major and independent cardiovascular risk factors. A meta-analysis of 21 prospective cohort studies showed that persons with the metabolic syndrome have a $61 \%$ higher risk of cardiovascular disease than individuals without the metabolic syndrome [5].

In general, immigrants from the Middle East perceived their general health as poorer than persons in the native population in Western countries [6-8]. According to an Irish $[9,10]$ and a Danish study $[9,10]$, immigrants from the Middle East have a higher prevalence of type 2 diabetes, higher risk of diabetic complications and with worse glycemic control than native patients. A recently published review of 17 articles on diabetes in Nordic countries concluded that immigrant groups had up to ten times higher risk than the non-immigrant populations; excess risk was particularly striking high in immigrants from the Middle East and South Asian regions [11]. Several Swedish studies show that the prevalence of diabetes in persons from nonEuropean and Middle Eastern countries is three to four times higher than in Swedish-born subjects [12,13]. The Middle Eastern immigrants have a higher prevalence of overweight and develop type 2 diabetes earlier in life than Swedish-born subjects. Possible contributing factors include stress caused by changes in lifestyle following migration [12,14]. Other factors related to migration also may increase the prevalence of overweight and obesity. Such factors may include urbanization, mechanization, changes in nutrition and lifestyle factors $[14,15]$. Furthermore, immigrants from the Middle East who have type 2 diabetes have a higher prevalence of firstdegree relatives with the disease, an earlier disease onset and a different form of type 2 diabetes than Swedish-born patients [16].

There are contrary findings about cardiovascular risk factors and cardiovascular diseases in immigrants and the native population in Sweden. Some Swedish studies showed higher incidence rates of cardiovascular and coronary heart diseases in immigrants than in Swedish-born individuals $[17,18]$. Researchers attribute these findings to a higher prevalence of abdominal obesity and higher levels of lipids in immigrants [17] as well as to lifestyle factors [18]. However, in an earlier analysis focused solely on cardiovascular risk factors in the current study population, we found a higher prevalence of elevated triglycerides and hypertension in Swedish persons with type 2 diabetes than in Assyrians/Syrians with the disease. This higher prevalence could not be explained by sociodemographic factors alone [14].

*Corresponding author: Marina Taloyan, Karolinska Institutet, Center for Family and Community Medicine, Alfred Nobels allé 12, SE -141 83 Huddinge, Sweden, E-mail: marina.taloyan@sll.se

Received October 23, 2010; Accepted November 17, 2010; Published November 19,2010

Citation: Taloyan M, Saleh-Stattin N, Johansson SE, Agréus L, Wändell P (2010) Differences in Cardiovascular Risk Factors in Swedes and Assyrians/Syrians with Type 2 Diabetes: Association with Lifestyle-Related Factors. J Diabet Metabol 1:110. doi:10.4172/2155-6156.1000110

Copyright: @ 2010 Taloyan M, et al. This is an open-access article distributed under the terms of the Creative Commons Attribution License, which permits unrestricted use, distribution, and reproduction in any medium, provided the original author and source are credited. 
Citation: Taloyan M, Saleh-Stattin N, Johansson SE, Agréus L, Wändell P (2010) Differences in Cardiovascular Risk Factors in Swedes and Assyrians/ Syrians with Type 2 Diabetes: Association with Lifestyle-Related Factors. J Diabet Metabol 1:110. doi:10.4172/2155-6156.1000110

Page 2 of 7

The present study compared cardiovascular risk factors and lifestyle-related factors in ethnic Assyrians/Syrians and Swedes with type 2 diabetes living in the same town in Sweden. Aims were [1] to determine the prevalence of some cardiovascular risk factors among Assyrians/Syrians and Swedes with type 2 diabetes and [2] to study whether the association between ethnicity and cardiovascular risk factors remained after adjusting for age, sex and lifestylerelated factors (BMI, total weekly physical activity in winter, alcohol consumption and smoking).

\section{Materials and Methods}

\section{Study population}

A total of 354 individuals with type 2 diabetes were examined in a health survey at four primary health care centers in the town of Södertälje. The study population included people from two ethnic groups: Assyrians/Syrians $(n=173)$ and Swedes $(n=181)$. Neither the register of patients at the health care centers nor official Swedish statistics include information on ethnicity; rather, persons are identified by country of birth, parents' country of birth and citizenship. For this reason, identification of prospective participants was done first by using participants' surnames and the health care center personnel's personal knowledge of patients. The first author and the health care center personnel then identified persons they believed to be ethnic Assyrians/Syrians or Swedes and a list of possible respondents was developed by the first author. Later, prospective responders were contacted by phone by the first author, a GP, or a nurse and invited to a face-to-face interview to fill out the questionnaire. Each interview was conducted either by the first author or one of six participating GPs at the primary health care centers. Interpreters were used at interviews as needed. At the interview, all participants who had been provisionally identified as Swedes were asked "Are you Swedish?" Those who answered "no" were asked additional questions about country of birth and ethnic identity and if they did not identify themselves as Assyrians/Syrians, were excluded from the study population. Participants who were provisionally identified as Assyrians/Syrians were asked the questions about country of birth and ethnic identity.

All Assyrians/Syrians came from Middle Eastern countries or were the children of parents who came from Middle Eastern Countries. Most of them came from Turkey (33.5\%), Iraq (30.6\%), or Syria (20.2\%). The remaining group came from Lebanon or other countries.

\section{Data sources}

Data on most variables, including ethnicity, age, sex, total weekly physical activity, alcohol consumption and smoking were collected in the face-to-face interview described above. Anthropometric variables (abdominal obesity and BMI) and blood pressure were measured by the first author or by a GP after each interview. Laboratory data (HbA1c, elevated triglycerides, elevated total cholesterol) were gathered from patients' medical records after obtaining verbal informed consent.

\section{Explanatory variables}

Age was divided into three groups: $32-59,60-69$ and $\geq 70$ years. Ethnicity was defined on the basis of the questions "Are you Swedish?" and "Did you belong to any ethnic, linguistic, or religious minority in the country where you grew up?" Persons were included in the study population if they identified themselves either as Assyrians/ Syrians or Swedes. The Assyrian/Syrian group included both first and second generation immigrants; i.e., persons born outside Sweden and persons born in Sweden to Assyrian/Syrian parents. The Swedish group included all persons who identified themselves as Swedish.

Anthropometric variables included height, weight, abdominal obesity and body mass index (BMI). BMI was calculated as weight divided by height squared. Abdominal obesity was defined as a waist circumference of $\geq 102 \mathrm{~cm}$ in men and $\geq 88 \mathrm{~cm}$ in women on the basis of established guidelines for adults [19].

Total weekly physical activity in winter was self-reported, included occupational and household physical activity as well as exercise and was based on two validated questions: one on physical activity in the summer and the other on physical activity in the winter. Each question had seven response alternatives: [1] $<1$ hour per week, [2] 1-2 hours per week, [3] 3-5 hours per week, [4] 6-10 hours per week, [5] 11-20 hours per week, [6] 21-30 hours per week and [7] > 30 hours per week. We divided participants into three groups. Those who chose alternative 1 or 2 were categorized as having $\leq 2$ hours of total physical activity each week. Those who chose alternative 3 were categorized as having 3-5 hours of total physical activity each week and those who chose alternative $4,5,6$, or 7 were categorized as having $\geq 6$ hours of total physical activity each week. [20]:

Alcohol consumption was based on the answers to two questions

1. Do you drink alcohol? Response alternatives were "often," "sometimes," and "never."

2. Do you drink at least half a bottle of spirits or a couple of bottles of wine per week? Response alternatives were "often," "sometimes," and "never."

Participants who answered "never" in response to both questions were defined as low consumers. Those who responded that they often or sometimes drank alcohol and often drank at least half a bottle of spirits or a couple of bottles of wine per week were defined as high consumers. The rest were defined as moderate consumers.

Smoking was defined on the basis of the question "Are you a daily smoker? (Yes/No)". Those who answered yes were categorized as daily smokers and those who answered no were categorized as nonsmokers.

\section{Outcome variables}

$H b A 1 c$ was divided into two groups: normal $(\leq 6.0 \%)$ and elevated ( $>6.0 \%$ ) according to the Swedish mono-S method, the standard method in Sweden for defining the limits of normal and elevated HbA1c. The limit of 6\% differs from the world standard, the Diabetes Control and Complications Trial (DCCT) standard, in which $>7 \%$ HbA1c is defined as elevated [21].

Cardiovascular Risk Factors included triglycerides, total cholesterol and hypertension. Triglycerides were divided into normal $(<1.7 \mathrm{mmol} / \mathrm{L})$ and elevated $(\geq 1.7 \mathrm{mmol} / \mathrm{L})$. Total cholesterol was divided into two groups: normal $(<4.5 \mathrm{mmol} / \mathrm{L})$ and elevated $(\geq$ $4.5 \mathrm{mmol} / \mathrm{L}$ ). To ascertain if participants had hypertension, blood pressure was measured in the right arm with the participant in the sitting position following 5 minutes of rest after the interview by the first author or participating GPs. The instrument used was a Boso Medicus Prestige Digital Sphygmomanometer with two different adult cuff sizes. Systolic blood pressure was dichotomized according to the International Diabetes Federation's guidelines for persons with type 2 diabetes (22) as normal $(\leq 130 \mathrm{mmHg})$ and high $(>130$ $\mathrm{mmHg})$. Diastolic blood pressure was divided into normal $(\leq 80$ 
$\mathrm{mmHg}$ ) and high (> $80 \mathrm{mmHg})$. If either the systolic blood pressure was $>130 \mathrm{mmHg}$ and/or the diastolic blood pressure was $>80$ $\mathrm{mmHg}$, the participant was considered to be hypertensive.

\section{Statistical analyses}

The prevalence of the outcome variables - HbA1c and cardiovascular risk factors, was estimated separately by ethnicity using the statistical software program Stata v.9 [23]. The tests of level of significance in the prevalence of elevated HbA1c, triglycerides and total cholesterol as well as hypertension were performed by using Pearson's chi-square test and the $t$ test. Unconditional logistic regression was used to calculate the odds ratios (ORs) and 95\% confidence intervals (CIs) of the association between outcome variables and explanatory variables. The fit of the models was assessed by the Hosmer-Lemeshow goodness-of-fit test. The models were considered acceptable if $\mathrm{p}>0.05$ and all models met this demand [24].

\section{Ethical considerations}

The study was approved by the Regional Ethical Committee of the Karolinska Institute (reference no. 2006/4:8, 2006-09-27).

\begin{tabular}{|c|c|c|c|}
\hline $\begin{array}{l}\text { Sociodemographic and } \\
\text { explanatory variables }\end{array}$ & Swedes $n=181$ & $\begin{array}{l}\text { Assyrians/ } \\
\text { Syrians } n=173\end{array}$ & $\begin{array}{l}\text { Test of } \\
\text { differences P-value }\end{array}$ \\
\hline $\begin{array}{l}\text { Total percent of study } \\
\text { population by ethnicity }\end{array}$ & 51.1 & 48.9 & \\
\hline \multicolumn{4}{|l|}{ Sex } \\
\hline Women & 44.2 & 48.5 & 0.411 \\
\hline Men & 55.8 & 51.5 & \\
\hline \multicolumn{4}{|l|}{ Age in years } \\
\hline $32-59$ & 32.6 & 46.5 & 0.026 \\
\hline $60-69$ & 32.6 & 27.3 & \\
\hline$\geq 70$ & 34.8 & 26.2 & \\
\hline \multicolumn{4}{|l|}{ Anthropometry } \\
\hline Weight in kg & $87(19.1)$ & $82(17.5)$ & 0.012 \\
\hline Height in $\mathrm{cm}$ & $170(9.6)$ & $162(9.9)$ & 0.000 \\
\hline $\begin{array}{l}\text { Mean BMI (standard } \\
\text { deviation) }\end{array}$ & $30(6.0)$ & $33(20.2)$ & 0.059 \\
\hline \multicolumn{4}{|l|}{ BMI groups } \\
\hline Normal $(<25)$ & 15.0 & 11.8 & 0.017 \\
\hline Overweight $(25.0-29.9)$ & 42.5 & 30.6 & \\
\hline Obese $(\geq 30)$ & 42.5 & 57.6 & \\
\hline Abdominal obesity & $106.3(13.8)$ & $106.1(12.1)$ & 0.877 \\
\hline Female $(>88 \mathrm{~cm})$ & 90.0 & 95.2 & 0.205 \\
\hline Male $(>102 \mathrm{~cm})$ & 59.4 & 54.0 & 0.447 \\
\hline \multicolumn{4}{|c|}{ Total weekly physical activity (hours) } \\
\hline Summer & & & 0.700 \\
\hline$\leq 2$ & 25.8 & 26.2 & \\
\hline $3-5$ & 67.4 & 69.2 & \\
\hline$\geq 6$ & 6.8 & 4.6 & \\
\hline Winter & & & 0.001 \\
\hline$\leq 2$ & 41.0 & 60.5 & \\
\hline $3-5$ & 54.5 & 37.8 & \\
\hline$\geq 6$ & 4.5 & 1.7 & \\
\hline Alcohol consumption & & & 0.000 \\
\hline High & 3.9 & 3.7 & \\
\hline Moderate & 79.1 & 43.3 & \\
\hline Never & 17.0 & 53.0 & \\
\hline \multicolumn{4}{|l|}{ Smoking } \\
\hline Daily smoker & 18.3 & 16.9 & 0.717 \\
\hline
\end{tabular}

Table 1: Distribution of background variables in percent and anthropometric variables by means and standard deviations in Assyrians/Syrians and Swedish patients with type 2 diabetes, $n=354$.

\begin{tabular}{|c|c|c|c|c|}
\hline \multirow[t]{2}{*}{ Variables } & \multicolumn{2}{|c|}{$\begin{array}{l}\text { Triglycerides } \\
(\geq 1.7 \mathrm{mmol} / \mathrm{L})\end{array}$} & \multicolumn{2}{|c|}{$\begin{array}{l}\text { Hypertension (systolic }>130 \\
\mathrm{~mm} \mathrm{Hg} \text { or diastolic }>80 \mathrm{~mm} \mathrm{Hg} \text { ) }\end{array}$} \\
\hline & Swedish & Assyrian/Syrian & Swedish & Assyrian/Syrian \\
\hline Mean & $2.1(1.0)$ & $1.7(1.0)$ & $\begin{array}{l}136.2(17.3) / \\
78.5(11.3)\end{array}$ & $\begin{array}{l}137.0(15.6) / \\
78.6(9.1)\end{array}$ \\
\hline Totals & $61.5^{a}$ & 39.7 & 77.0 & 58.0 \\
\hline \multicolumn{5}{|l|}{ Age } \\
\hline $32-59$ & 56.0 & 37.0 & 76.3 & 47.5 \\
\hline $60-69$ & 67.0 & 38.5 & 69.5 & 62.0 \\
\hline$\geq 70$ & 62.0 & 47.1 & 84.1 & 71.1 \\
\hline \multicolumn{5}{|l|}{ Sex } \\
\hline Women & 68.3 & 40.0 & 76.3 & 54.2 \\
\hline Men & 56.5 & 39.5 & 77.2 & 61.0 \\
\hline \multicolumn{5}{|l|}{ BMI } \\
\hline Normal & 37.0 & 32.0 & 78.0 & 55.0 \\
\hline Overweight & 65.2 & 45.2 & 80.3 & 52.0 \\
\hline Obese & 66.1 & 39.0 & 75.0 & 61.2 \\
\hline \multicolumn{5}{|c|}{ Abdominal obesity } \\
\hline $\begin{array}{l}\text { Women } \\
(>88)\end{array}$ & 68.4 & 41.0 & 75.0 & 54.4 \\
\hline Men (>102) & 58.0 & 41.5 & 82.0 & 60.4 \\
\hline \multicolumn{5}{|c|}{ Total physical activity (hours/week) } \\
\hline$\leq 2$ & 70.2 & 45.4 & 78.1 & 58.0 \\
\hline $3-5$ & 57.0 & 32.0 & 76.3 & 57.0 \\
\hline$\geq 6$ & 43.0 & 33.3 & 75.0 & 67.0 \\
\hline \multicolumn{5}{|c|}{ Alcohol consumption } \\
\hline High & 100.0 & 25.0 & 100.0 & 67.0 \\
\hline Moderate & 61.2 & 33.3 & 78.5 & 56.3 \\
\hline Never & 61.1 & 46.0 & 77.0 & 57.5 \\
\hline \multicolumn{5}{|l|}{ Smoking } \\
\hline $\begin{array}{l}\text { Daily } \\
\text { smoker }\end{array}$ & 52.0 & 26.0 & 69.0 & 52.0 \\
\hline Nonsmoker & 65.0 & 43.0 & 81.6 & 57.0 \\
\hline
\end{tabular}

aBolt number indicate a statistically significant difference between Swedes and Assyrians/Syrians

Table 2: Prevalence (\%) and means (standard deviations) of the outcome variables elevated triglycerides and hypertension in Assyrian/Syrian and Swedish patients with type 2 diabetes by ethnicity.

\section{Results}

The test of differences in the 173 Assyrian/Syrian and 181 Swedish patients with type 2 diabetes showed statistically significant differences in age and anthropometric variables (Table 1). The mean age of the Swedish participants was 64 years (range 32 to 86 years), whereas Assyrian/Syrian participants were younger; their mean age was 61 years (range 32 to 83 years). Assyrians/Syrian participants had a mean weight of $82 \mathrm{~kg}$ and a mean height of $162 \mathrm{~cm}$, whereas the mean weight of Swedish participants was $87 \mathrm{~kg}$ and the mean height was $170 \mathrm{~cm}$. No significant differences were observed in mean BMI, which was 33 in the Assyrians/Syrians and 30 in the Swedes. However, there were significant differences in prevalence of normal weight, overweight and obesity between the groups: normal weight and overweight were more prevalent in Swedes than in Assyrians/ Syrians, whereas obesity was more prevalent in Assyrians/Syrians than in Swedes. The proportion of individuals with $\geq 3$ hours of total physical activity in the winter was significantly higher in Swedes than in Assyrians/Syrians. More than half of the Assyrians/Syrians but only $17 \%$ of the Swedes reported that they never used alcohol. A higher proportion of Swedes (79.1\%) than Assyrians/Syrians (43.3\%) reported moderate alcohol consumption.

\section{HbA1C and cardiovascular risk factors}

The prevalences of elevated triglyceride levels and hypertension 
are shown in (Table 2) Elevated triglycerides and hypertension were more prevalent in Swedes than in Assyrians/Syrians. There were no other significant differences between groups with regard to total cholesterol or $\mathrm{HbA1c}$ level.

The prevalences of the outcome variables by explanatory variables and ethnicity are also shown in (Table 3). There were no differences by sex within either ethnic group regarding outcome variables. However, elevated triglycerides were more prevalent in Swedish (70.0\%) women than Assyrian/Syrian women (41.2\%) and in Swedish men (58.3\%) than in Assyrian/Syrian men (37.8) (Table 4). The same pattern was observed in the prevalence of hypertension, which was $81.5 \%$ in Swedish women and $53.8 \%$ in Assyrian/Syrian women and $76.4 \%$ in Swedish men and 61.0 in Assyrian/Syrian men.

In addition to the differences by ethnicity and sex discussed above, we found a significantly higher prevalence of hypertension in other specific groups of Swedes than in equivalent Assyrian/ Syrian groups. These groups included those aged 32 to 57 years, those who were overweight, women with abdominal obesity, men with abdominal obesity, those who engaged in $<6$ hours of physical activity each week, moderate consumers of alcohol and non-smokers. The prevalence of abnormal HbA1c levels was significantly higher in Assyrian/Syrians who were overweight and in Assyrians/Syrians who were nonsmokers than in Swedes in the same groups. The prevalence of elevated total cholesterol in Swedish nonsmokers was significantly higher than in Assyrian/Syrian nonsmokers.

\section{Logistic regression}

The odds in the crude logistic regression models for elevated triglycerides and hypertension were more than two and half times higher among Swedes (OR 2.70, 95\% CI 1.61-4.50 and OR 2.80, 95\% Cl 1.70-4.60, respectively) (not shown in Table). Crude ORs of elevated levels of $\mathrm{HbA} 1 \mathrm{c}$ and total cholesterol were similar among Swedes (OR 1.31, 95\% Cl 0.83-2.10) and Assyrians/Syrians (OR 1.30, 95\% CI 0.822.30) (not shown in Table).

The results of the final logistic regression models showing the association between ethnicity and odds of four outcome variables, adjusted for age, sex, BMI, total physical activity, alcohol consumption and smoking are shown in (Table 5) Model 1 shows that there were no significant differences between Assyrians/Syrians and Swedes in odds of elevated levels of HbA1c ( $>6 \%$ ). Model 2 shows that Swedes had higher odds of elevated triglycerides (OR 3.74, 95\% CI 2.00-7.20) than Assyrians/Syrians. Odds of hypertension were approximately three times higher in Swedes than in Assyrians/Syrians (OR 2.95, 95\% CI 1.61-5.41). Thus, the differences between the two ethnic groups with regard to hypertension and elevated triglycerides remained significant after adjustment for the all explanatory variables.

There were no differences between the two ethnic groups regarding odds of elevated cholesterol levels. Women had higher odds of elevated total cholesterol than men (OR 1.70, 95\% CI 1.002.90) (not shown in Table) after adjustment for age, sex, BMI and total physical activity. This difference disappeared when alcohol consumption was added as an explanatory variable in the logistic regression model: the OR decreased to $1.64,95 \%$ CI 0.92-2.91 (not shown in Table) and was no longer significant. In the regression analyses, the only significant confounder of the odds of increased Hba1c was age group. Those in the group aged 60-69 years had significantly lower odds of elevated levels of Hba1c than those in the 32-59 year-old group or those in the $\geq 70$ year-old group, even after stepwise inclusion of the all explanatory variables separately (not shown in Table). Furthermore, age was a significant confounder in both the age- and sex-adjusted and full models. In the age- and sex-adjusted model, 2.54 times higher odds $(95 \% \mathrm{CI} 1.33-4.83)$ of hypertension were found in those aged $\geq 70$ years than in those in younger age groups (32-59 and 60-69). In the final model, the odds of having hypertension in those $\geq 70$ years increased to $3.35(95 \% \mathrm{Cl}$ 1.50-6.50).

\section{Discussion}

The main findings of this study are the differences in prevalence and odds of elevated serum triglycerides and hypertension between Swedes and Assyrians/Syrians with type 2 diabetes. Swedes had more than three and half times higher odds of elevated serum triglycerides than Assyrians/Syrians. The same pattern was observed regarding hypertension: odds remained significantly higher in Swedes after adjustment for all explanatory variables.

A number of previous studies suggest that ethnicity is important in diabetes and a number of studies have shown that immigrants from the Middle East have a higher prevalence of diabetes than persons in the non-immigrant population [12,13,15,25-27].

A review of 18 studies on cardiovascular risk factors and cardiovascular disease in two immigrant groups in North West Europe found a higher prevalence of type 2 diabetes in Turkish and Moroccan immigrants than in indigenous Dutch study populations but a lower prevalence of type 2 diabetes in Turkish women than in indigenous German women [28]. One German study found that Turkish men and women had lower age-adjusted cardiovascular disease mortality rates than German men and women [28]. Because

\begin{tabular}{|l|l|l|l|l|l|l|}
\hline & \multicolumn{3}{l|}{ Swedish } & \multicolumn{3}{l|}{ Assyrian/Syrian } \\
\hline Variable & Women & Men & Pr-value & Women & Men & Pr-value \\
\hline & $\begin{array}{l}\mathrm{N}=101 \\
(55.8)\end{array}$ & $\begin{array}{l}\mathrm{N}=80 \\
(44.2)\end{array}$ & & $\begin{array}{l}\mathrm{N}=89 \\
(51.7)\end{array}$ & $\begin{array}{l}\mathrm{N}=83 \\
(48.3)\end{array}$ & \\
\hline HbA1c & & & & & & \\
\hline$>6$ & 46.0 & 40.9 & 0.545 & 53.2 & 43.1 & 0.437 \\
\hline Triglycerides & & & & & & \\
\hline$\geq 1.7 \mathrm{mmol} / \mathrm{L}$ & 70.0 & 58.3 & 0.205 & 41.2 & 37.8 & 0.684 \\
\hline Total cholesterol & & & & & & \\
\hline$\geq 4.5 \mathrm{mmol} / \mathrm{L}$ & 74.5 & 62.5 & 0.171 & 67.1 & 55.4 & 0.106 \\
\hline Hypertension & & & & & & \\
\hline$>130$ or $>80$ & 81.5 & 76.4 & 0.461 & 53.8 & 60.9 & 0.349 \\
\hline
\end{tabular}

Table 3: Prevalence (\%) of the outcome variables increased $\mathrm{HbA} 1 \mathrm{c}$, elevated triglycerides, elevated total cholesterol, and hypertension (systolic/diastolic) in Assyrian/Syrian and Swedish patients with type 2 diabetes by ethnicity and sex and test of differences in distribution by ethnicity (Pr-value).

\begin{tabular}{|c|c|c|c|c|c|c|}
\hline \multirow[b]{2}{*}{ Variable } & \multirow{2}{*}{$\begin{array}{l}\text { Swedish } \\
\text { Women }\end{array}$} & \multicolumn{2}{|c|}{ Assyrian/Syrian } & \multirow{2}{*}{$\begin{array}{l}\text { Swedish } \\
\text { Men }\end{array}$} & \multicolumn{2}{|c|}{ Assyrian/Syrian } \\
\hline & & Women & Prvalue & & Men & Pr value \\
\hline & $\begin{array}{l}\mathrm{N}=101 \\
(55.8)\end{array}$ & $\begin{array}{l}\mathrm{N}=80 \\
(44.2)\end{array}$ & & $N=$ & $\begin{array}{l}\mathrm{N}=83 \\
(48.3)\end{array}$ & \\
\hline \multicolumn{7}{|l|}{ HbA1c } \\
\hline$>6 \%$ & 46.0 & 53.2 & 0.398 & 40.9 & 47.1 & 0.429 \\
\hline \multicolumn{7}{|c|}{ Triglycerides } \\
\hline$\geq 1.7 \mathrm{mmol} / \mathrm{L}$ & 70.0 & 41.2 & 0.002 & 58.3 & 37.8 & 0.018 \\
\hline \multicolumn{7}{|c|}{ Total cholesterol } \\
\hline$\geq 4.5 \mathrm{mmol} / \mathrm{L}$ & 74.5 & 67.1 & 0.372 & 62.5 & 54.4 & 0.331 \\
\hline \multicolumn{7}{|c|}{ Hypertension } \\
\hline$>130 \mid>80$ & 81.5 & 53.8 & 0.000 & 76.4 & 61.0 & 0.038 \\
\hline
\end{tabular}

Table 4: Prevalence (\%) of the outcome variables increased $\mathrm{HbA} 1 \mathrm{c}$, elevated triglycerides, elevated total cholesterol and hypertension (systolic/diastolic) in Assyrian/Syrian and Swedish patients with type 2 diabetes by ethnicity and sex and test of differences of distribution by sex (Pr-value). 
Citation: Taloyan M, Saleh-Stattin N, Johansson SE, Agréus L, Wändell P (2010) Differences in Cardiovascular Risk Factors in Swedes and Assyrians/ Syrians with Type 2 Diabetes: Association with Lifestyle-Related Factors. J Diabet Metabol 1:110. doi:10.4172/2155-6156.1000110

Page 5 of 7

\begin{tabular}{|c|c|c|c|c|}
\hline Variable & Model 1 (HbA1c) & Model 2 (triglycerides) & Model 3 (cholesterol) & Model 4 (hypertension) \\
\hline \multicolumn{5}{|l|}{ Ethnicity } \\
\hline Assyrians/Syrians (reference) & 1 & 1 & 1 & 1 \\
\hline Swedes & $1.05(0.61-1.80)$ & $3.74(2.00-7.20)$ & $1.32(0.73-2.42)$ & $2.95(1.61-5.41)$ \\
\hline \multicolumn{5}{|l|}{ Age groups (years) } \\
\hline 32-59 (reference) & 1 & 1 & 1 & 1 \\
\hline $60-69$ & $0.52(0.29-0.94)$ & $1.23(0.70-2.40)$ & $1.13(0.61-2.11)$ & $1.25(0.70-2.30)$ \\
\hline$\geq 70$ & $0.54(0.29-1.01)$ & $0.94(0.45-2.00)$ & $1.70(0.83-3.46)$ & $3.10(1.50-6.50)$ \\
\hline \multicolumn{5}{|l|}{ Sex } \\
\hline Men (reference) & 1 & 1 & 1 & 1 \\
\hline Women & $1.14(0.68-1.50)$ & $1.20(0.70-2.20)$ & $1.64(0.92-2.91)$ & $1.05(0.60-1.90)$ \\
\hline \multicolumn{5}{|l|}{ BMI } \\
\hline$<25$ (reference) & 1 & 1 & 1 & 1 \\
\hline $25.0-29.9$ & $0.80(0.35-1.66)$ & $1.92(0.80-4.84)$ & $2.01(0.88-4.61)$ & $0.90(0.40-2.04)$ \\
\hline$\geq 30$ & $0.97(0.44-2.11)$ & $1.64(0.70-4.10)$ & $1.93(0.85-4.42)$ & $1.41(0.60-3.31)$ \\
\hline \multicolumn{5}{|c|}{ Total weekly physical activity in winter (hours/week) } \\
\hline$\leq 2$ (reference) & 1 & 1 & 1 & 1 \\
\hline $3-5$ & $0.66(0.40-.10)$ & $0.60(0.32-1.02)$ & $1.30(0.75-2.30)$ & $1.12(0.64-2.00)$ \\
\hline$\geq 6$ & $0.30(0.10-1.71)$ & $0.30(0.04-1.70)$ & $1.23(0.24-6.30)$ & $1.73(0.30-10.80)$ \\
\hline \multicolumn{5}{|l|}{ Alcohol consumption } \\
\hline Never (reference) & 1 & 1 & 1 & 1 \\
\hline High+Moderate & $0.82(0.46-1.48)$ & $0.70(0.33-1.31)$ & $0.95(0.50-1.80)$ & $1.02(0.54-1.91)$ \\
\hline \multicolumn{5}{|l|}{ Smoking } \\
\hline Nonsmoker (reference) & 1 & 1 & 1 & 1 \\
\hline Daily smoker & $0.71(0.40-1.40)$ & $0.60(0.30-1.22)$ & $0.97(0.48-1.94)$ & $0.75(0.40-1.52)$ \\
\hline
\end{tabular}

Table 5: The odds ratios (ORs) with 95\% confidence intervals (Cl 95\%) of elevated HbA1c (Model 1), elevated triglycerides (Model 2), elevated total cholesterol (Model 3) and hypertension (Model 4 ) in Swedes and Assyrians/Syrians with type 2 diabetes as the reference group after adjusting for all explanatory variables.

of a lack of valid studies on blood pressure and lipids in the studies in this review, it was not possible to compare our results on blood pressure and lipids with the results of the studies in the review. On the basis of the present study's findings of higher prevalence and odds of elevated triglycerides levels and hypertension in Swedes than Assyrians/Syrians, it is possible to speculate that in Sweden, Swedes are at higher risk of coronary events than Assyrians/Syrians.

Available data from 2007 on diabetic patients in Sweden registered with the National Diabetes Register (NDR) [4] make it possible to compare our results with countrywide results. According to the NDR, $55.5 \%$ of the population included in the register reach the target for an acceptable level of triglycerides $(<1.7 \mathrm{mmol} / \mathrm{L})$, which is quite similar to our results in Swedes (38.5\%) and lower than in Assyrians/Syrians (61.3\%). The number of individuals with normal blood pressure $(\leq 130 / 80 \mathrm{mmHg})$ in the register $(35 \%)$ is higher than in the Swedes in the present study (23.0\%) and lower than in Assyrians/ Syrians in the study $(42.0 \%)$.

A recently published Swedish study of 4,228 60-year-olds that included native Swedes, immigrants from Finland and immigrants from non-European countries living in Sweden showed a pattern of hypertension ORs similar to the pattern of ORs found in this study; that is, the non-European immigrant group had the lowest ORs of hypertension [29]. Because the definition of hypertension in the study on 60 -year-olds was based on 140/90 $\mathrm{mm} \mathrm{Hg}$ rather than $130 / 80 \mathrm{~mm}$ $\mathrm{Hg}$ as in the current study and because of the lack of information on chronic diseases in the study on 60-year-olds, it was not possible to do an exact comparison of the results of the two studies.

Our finding of higher prevalence of elevated triglycerides in Swedish men and women than in Assyrian/Syrian men and women is not consistent with data on the pattern of blood lipid disturbances among non-European immigrants in Sweden from the recent study on 60-year-old men and women in Stockholm. According to this study, non-European immigrants had a higher OR of elevated triglycerides than Swedish-born men and women [29]. We believe that further studies of elevated triglycerides and nutritional habits in Sweden are needed. Such studies should have larger sample sizes and should include separate analyses of each ethnic group. Analyses should compare the association between triglycerides and nutritional habits in patients with type 2 diabetes with triglycerides and nutritional habits in control groups without diabetes. We agree with conclusion of the study on 60-year-olds that genetic background should be included as a factor in the analyses to investigate whether genetic background may play a role in elevated levels of blood lipids.

Additionally, the non-European immigrants in the study on 60 -year-olds had lower ORs of elevated total cholesterol than Swedish-born men and women [29], whereas we found no significant difference in prevalence of elevated total cholesterol in Assyrians/ Syrians and Swedes. It should be noted, however, that our data only included information on total cholesterol, whereas Wändell et al. were able to analyze ORs of high HDL and low LDL cholesterol. They found lower risk of high LDL and higher risk of low HDL cholesterol in non-European immigrants than Swedish-born men and women.

Elevated triglyceride levels contribute independently to an increased risk of cardiovascular disease and in combination with factors such as obesity, the metabolic syndrome and type 2 diabetes, affects cardiovascular disease risk $[30,31]$.

Our findings of differences in lipids between ethnic groups are in accord with the results of other studies. One similar finding comes from a Swedish follow-up study that investigated possible social predictors of reduction of hyperlipidaemia [32]. The study focused on lifestyle interventions such as improved diet, exercise, weight-control and stress management in 1904 individuals with raised cholesterol and triglycerides levels. The researchers found that successful reduction of high cholesterol levels was associated 
Citation: Taloyan M, Saleh-Stattin N, Johansson SE, Agréus L, Wändell P (2010) Differences in Cardiovascular Risk Factors in Swedes and Assyrians/ Syrians with Type 2 Diabetes: Association with Lifestyle-Related Factors. J Diabet Metabol 1:110. doi:10.4172/2155-6156.1000110

Page 6 of 7

with younger age and longer participation in education program for cardiovascular disease prevention. In addition, foreign-born participants in the study achieved a somewhat higher success rate in reducing hypercholesterolaemia than did Swedish-born participants [32]. Other studies done in Sweden have shown that higher BMI is associated with cardiovascular risk factors in elderly immigrants from Iran, as well [33] as with higher prevalence of diabetes in 60-yearold immigrants from non-European countries [13]. Furthermore, overweight/obesity and physical inactivity are considered as the most common factors increasing elevated serum triglycerides in general [34]. However, it seems possible that genetic factors also play a role. Results of the current study show that despite the significantly higher prevalence of obesity in Assyrians/Syrians (57.6\%) than in Swedes (42.5\%) triglyceride levels are higher in Swedes.

Food intake, especially increased carbohydrate intake, is a common reason for elevated triglycerides [31]. It is thus possible that something about the food intake (diet) of the Assyrians/ Syrians in this study affected their triglycerides. Assyrians/Syrians traditionally consume a diet that resembles the Mediterranean diet. The Mediterranean diet has been shown to significantly reduce total cholesterol, blood pressure and triglycerides [35]. Many Assyrians/ Syrians are Christians and follow the religious tradition known as "fasting" (going without food or restricting one's diet) at certain times of the year. Adherence to this tradition might also help explain the lower prevalence of elevated triglycerides in Assyrians/Syrians than in Swedes in this study, especially as the majority of Assyrians/ Syrians in our study reported that they were strongly religious, went to church quite often and viewed their diabetes as God's decision. The possible effect of Assyrian/Syrian dietary habits on blood lipid levels should be investigated in future prospective studies.

The major strength of this study is that this is the first survey describing a somewhat homogeneous Assyrian/Syrian ethnic group in which people identified their actual ethnicity instead of being classified on the basis of their country of birth or regional and geographic affiliations. Assyrians/Syrians are a large Christian minority group in Sweden who began immigrating to Sweden in the 1970s because of religious and political persecution [36]. The majority of Assyrians/Syrians in Europe came from Eastern Turkey and sought asylum in Sweden, Germany and France. Today there are about 20,000 Assyrians/Syrians from Turkey, Syria, Iraq and Lebanon living in Sweden. Most of them live in Södertälje, where 42.7\% of the total population consisted of first and second generation immigrants in 2009 [37]. Despite the large number of Assyrian/Syrian immigrants in Sweden, there is a lack of knowledge about diabetes in this group of people and the present study is one of the first investigations into this topic.

Despite the small sample size in this study, the Assyrians/Syrians in the study population can be considered representative of Assyrians/ Syrians in Sweden. The inclusion of participants from the same four primary health care centers helps eliminate specific factors related to the environment and neighborhood as significant confounders with an impact on health. Even if we cannot generalize our findings to all Assyrians/Syrians and Swedes in Sweden, the results of the study provide a reliable baseline for future studies.

A major limitation of the study is its cross-sectional nature, which precludes the possibility of drawing causal conclusions. A further limitation is the small sample size. Finally, we were not able to accurately estimate the number of Assyrians/Syrians immigrants in Sweden because they are registered as citizens of the countries from which they come rather than by ethnic group.
This study shows that differences in triglycerides and hypertension between Assyrians/Syrians and Swedes with type 2 diabetes could not be explained by differences in either anthropometric measurements or the lifestyle-related factors included in our analyses.

Future studies are needed to analyze other factors, including biological factors, which might help explain differences between the ethnic groups in the prevalence and ORs of triglycerides and hypertension. Longitudinal studies in the same area on cardiovascular events might help to clarify the factors explained ethnic differences in elevated triglycerides and hypertension between Swedes and Assyrian/Syrians.

\section{Acknowledgements}

This work was supported by grants from the Research Unit in Södertälje. The funding bodies played no role in the study design and the collection, analysis and interpretation of data, the writing of the manuscript, or the decision to submit the manuscript for publication. The authors have no conflicts of interest to report We thank all GPs at the four primary health care centers for help with gathering data. We also thank Scientific Editor Kimberly L. Kane of the Center for Family and Community Medicine for linguistic revision of the manuscript and valuable comments.

\section{References}

1. Ginsberg HN, MacCallum PR (2009) The obesity, metabolic syndrome and type 2 diabetes mellitus pandemic: Part I. Increased cardiovascular disease risk and the importance of atherogenic dyslipidemia in persons with the metabolic syndrome and type 2 diabetes mellitus. J Cardiometab Syndr 4: 113-119.

2. Kannel WB, McGee DL (1979) Diabetes and cardiovascular disease. The Framingham study. JAMA 241: 2035-2038.

3. Jansson SP, Andersson DK, Svardsudd K (2007) Prevalence and incidence rate of diabetes mellitus in a Swedish community during 30 years of follow-up. Diabetologia. 50: 703-710.

4. Diabetesregister (2008) N Diabetolog Nytt Göteborg: Swedish Society for Diabetology. Report No 21: 3

5. Galassi A, Reynolds K, He J (2006) Metabolic syndrome and risk of cardiovascular disease: a meta-analysis. Am J Med 119: 812-819.

6. Kahlin Y, Werner S, Romild U, Alricsson M (2009) Self-related health, physical activity, BMI and musculoskeletal complaints: a comparison between foreign and Swedish high school students. Int J Adolesc Med Health 21: 327-341.

7. Westman J, Martelin T, Harkanen T, Koskinen S, Sundquist K (2008) Migration and self-rated health: a comparison between Finns living in Sweden and Finns living in Finland. Scand J Public Health 36: 698-705.

8. Taloyan M (2008) Health, migration and quality of life among Kurdish immigrants in Sweden. Stockholm: Karolinska Institutet.

9. Thabit H, Martin G, Brema I, Daly M, Walsh S, et al. (2008) Immigrant patients with type 2 diabetes mellitus have poorer initial and on-going glycemic control than a matched population of Irish patients. Ir Med J 101: 177-180.

10. Kristensen JK, Bak JF, Wittrup I, Lauritzen T (2007) Diabetes prevalence and quality of diabetes care among Lebanese or Turkish immigrants compared to a native Danish population. Prim Care Diabetes 1: 159-165.

11. Wandell PE, Carlsson A, Steiner KH (2010)Prevalence of diabetes among immigrants in the Nordic countries. Curr Diabetes Rev 6: 126-133.

12. Wandell PE, Johansson SE, Gafvels C, Hellenius ML, de Faire U, et al. (2008) Estimation of diabetes prevalence among immigrants from the Middle East in Sweden by using three different data sources. Diabetes Metab 34: 328-333.

13. Wandell PE, Gafvels C (2007) High prevalence of diabetes among immigrants from non-European countries in Sweden. Prim Care Diabetes 1:13-16.

14. Misra A, Ganda OP (2007) Migration and its impact on adiposity and type 2 diabetes. Nutrition 23: 696-708.

15. Wandell PE, Hjorleifsdottir Steiner K, Johansson SE (2003) Diabetes mellitus in Turkish immigrants in Sweden. Diabetes Metab 29: 435-439.

16. Glans F, Elgzyri T, Shaat N, Lindholm E, Apelqvist J, et al. (2008) Immigrants from the Middle-East have a different form of Type 2 diabetes compared with Swedish patients. Diabet Med 25: 303-307. 
Citation: Taloyan M, Saleh-Stattin N, Johansson SE, Agréus L, Wändell P (2010) Differences in Cardiovascular Risk Factors in Swedes and Assyrians/ Syrians with Type 2 Diabetes: Association with Lifestyle-Related Factors. J Diabet Metabol 1:110. doi:10.4172/2155-6156.1000110

Page 7 of 7

17. Daryani A, Berglund L, Andersson A, Kocturk T, Becker W, et al. (2005) Risk factors for coronary heart disease among immigrant women from Iran and Turkey, compared to women of Swedish ethnicity. Ethn Dis 15: 213-220.

18. Gadd M, Sundquist J, Johansson SE, Wandell P (2005) Do immigrants have an increased prevalence of unhealthy behaviours and risk factors for coronary heart disease?. Eur J Cardiovasc Prev Rehabil 12: 535-541.

19. Alberti KG, Eckel RH, Grundy SM, Zimmet PZ, Cleeman JI, et al. (2009) Harmonizing the metabolic syndrome: a joint interim statement of the International Diabetes Federation Task Force on Epidemiology and Prevention; National Heart, Lung and Blood Institute; American Heart Association; World Heart Federation; International Atherosclerosis Society; and International Association for the Study of Obesity. Circulation 120: 1640-1645.

20. Theobald H, Bygren LO, Carstensen J, Engfeldt $P$ (1999) Validity of two questions on alcohol use in a health survey questionnaire. Scand $\mathrm{J}$ Public Health. 27: 73-77.

21. Eckerbom S, Bergqvist Y, Jeppsson JO (1994) Improved method for analysis of glycated haemoglobin by ion exchange chromatography. Ann Clin Biochem 31: $355-360$

22. International Diabetes Federation (2005) Blood pressure control. Global Guideline for Type 2 Diabetes Clinical Guidelines Task Force Chapter.

23. StataCorp (2007) Stata Statistical Software: Release 9.2. College station. TX: Stata Corporation.

24. Hosmer DL (2002) Applied Logistic Regression, 2nd edition. New York: John Wiley\&Sous Inc.

25. Pollard TM, Unwin N, Fischbacher C, Chamley JK (2008) Differences in body composition and cardiovascular and type 2 diabetes risk factors between migrant and British-born British Pakistani women. Am J Hum Biol 20: 545-549.

26. Fritz T, Wandell P, Aberg H, Engfeldt $P$ (2006) Walking for exercise--does three times per week influence risk factors in type 2 diabetes? Diabetes Res Clin Pract 71: 21-27.

27. Wandell PE, Bolinder G, de Faire U, Hellenius ML (2008) Association between metabolic effects and tobacco use in 60-year-old Swedish men. Eur J Epidemiol 23: $431-434$

28. Uitewaal PJ, Manna DR, Bruijnzeels MA, Hoes AW, Thomas S (2004) Prevalence of type 2 diabetes mellitus, other cardiovascular risk factors and cardiovascular disease in Turkish and Moroccan immigrants in North West Europe: a systematic review. Prev Med 39:1068-1076.

29. Wandell PE, Carlsson AC, Faire UD, Hellenius ML (2009) Prevalence of blood lipid disturbances in Swedish and foreign-born 60-year-old men and women in Stockholm, Sweden. Nutr Metab Cardiovasc Dis 23.

30. McBride $P$ (2008) Triglycerides and risk for coronary artery disease. Cur Atheroscler Rep 10: 386-390.

31. Yuan G, Al-Shali KZ, Hegele RA. Hypertriglyceridemia: its etiology, effects and treatment. CMAJ 2007 176: 1113-1120.

32. Hellenius ML, Nilsson P, Elofsson S, Johansson J, Krakau I (2005) Reduction of high cholesterol levels associated with younger age and longer education in a primary health care programme for cardiovascular prevention. Scand J Prim Health Care 23: 75-81.

33. Koochek A, Johansson SE, Kocturk TO, Sundquist J, Sundquist K (2008) Physical activity and body mass index in elderly Iranians in Sweden: a population-based study. Eur J Clin Nutr 62: 1326-1332.

34. Serra Majem L, Ribas Barba L, Salvador Castell G, Roman Vinas B, et al (2007) [Trends in the nutritional status of the Spanish population: results from the Catalan nutrition monitoring system (1992-2003)]. Rev Esp Salud Publica 81: 559-570.

35. Athyros VG, Kakafika Al, Papageorgiou AA, Tziomalos K, Peletidou A, et al (2009) Effect of a plant stanol ester-containing spread, placebo spread, or Mediterranean diet on estimated cardiovascular risk and lipid, inflammatory and haemostatic factors. Nutr Metab Cardiovasc Dis 23.

36. Westin C (2003) Young People of Migrant Origin in Sweden. International migrationReview 37: 987-1010.

37. Sodertälje C (2008) Facts on population in Södertälje Count. 